University of Massachusetts Amherst

ScholarWorks@UMass Amherst

Masters Theses 1911 - February 2014

1932

\title{
The mineral composition of dates
}

Maurice Mortimer Cleveland

University of Massachusetts Amherst

Follow this and additional works at: https://scholarworks.umass.edu/theses

Cleveland, Maurice Mortimer, "The mineral composition of dates" (1932). Masters Theses 1911 - February 2014. 1402.

Retrieved from https://scholarworks.umass.edu/theses/1402

This thesis is brought to you for free and open access by ScholarWorks@UMass Amherst. It has been accepted for inclusion in Masters Theses 1911 - February 2014 by an authorized administrator of ScholarWorks@UMass Amherst. For more information, please contact scholarworks@library.umass.edu. 


\title{
THE MUNERAL COMPOSTTION DF DATES
}

\author{
CIEVELAND - 1932
}
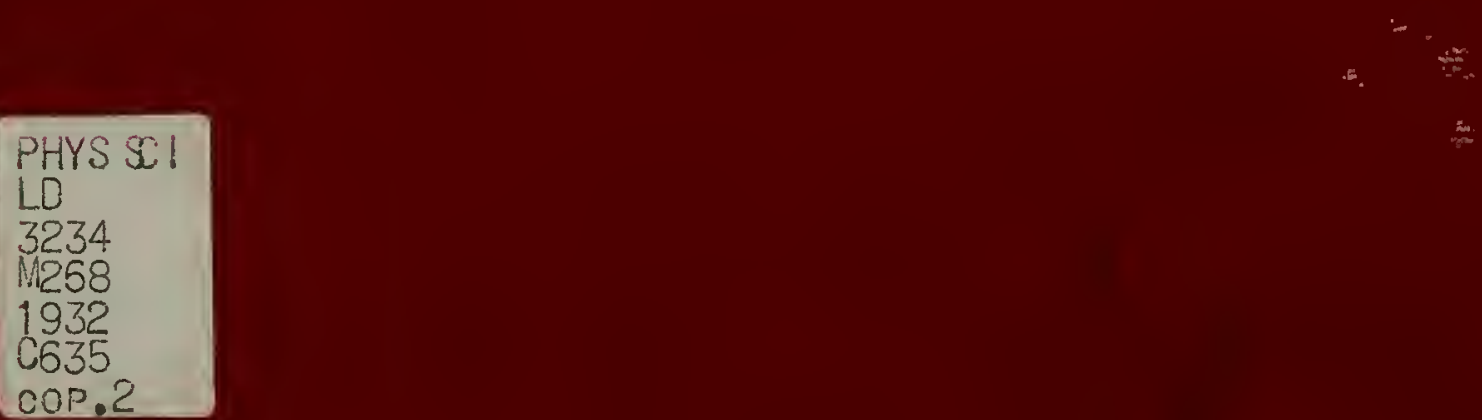


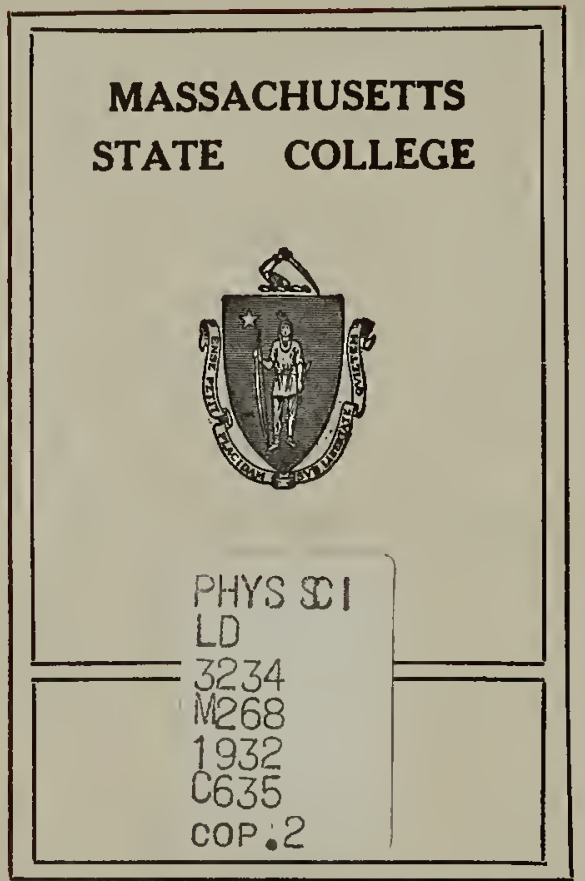


THE NIHERAL COKPOSITION OF DATES

Haurice lortimer cleveland

$$
\begin{aligned}
& \text { Thesis subltted for } \\
& \text { the degree of } \\
& \text { Waster of Science }
\end{aligned}
$$

HASSACIUSETTS STATE COLLTGE, AIATRST

June 1, 1932 
I. INTRODUCTIOH

Page 1

II. REVIEF OF LITLRATURE 3

1. General Chenleal Hature of the Date 3

2. Relation of composition to strage of Vaturity

3. Proximate Analyses

4

4. proportion of Edible portion to pit 7

5. Content of Gums and pectin 7

6. Vitamin Content 9

III. EXPTRIIMATAL PAHT 10

1. Analytical uethods 10

2. General Composition of the Ach 27

3. Content of Iron, Copper, Manganese 32

4. Content of Boric Acid 36

5. Alkalinity of the Ash 37

IV. SUIYYARY 40

v. BIBLIOGRAPHY 42

VI. AOKNOTLEDGEMENTS 46 


\section{IHTRODUCT ION}

The chemical composition of the date is of interest because of the widespread use of this frult as a human food. In the date-producing countries of the orient and northern Africa it is a principal component of the diet. France and Italy import many dates from their colonles across the Hediterranean. In England the annual consumption is 3 pounds per capita. In Canado and the United states it 18 respectively, 1 pound and 0.43 pounds. The date industry in California and Arizona 18 inportant and is growing rapidly. The present production is over $3,000,000$ pounds per year. The Aaerican grown dates, however, fumish only a small fraction of those consumed. Approximately 54,000,000 pounds of dates are imported annually, principally from Iraa at the head of the persian culf.

While there are many varieties of dates, only a few are of commercial importance. The Deglet Hoor is the principal American grown varlety, while the Hallowi, Sayer, and Khadraw comprise the sreater part of the annual import. The present paper is concerned particularly with the more important imported varieties, Hallowi and Sayer. The speciflc purpose of the author in this investigation was to obtain exact information regarding the mineral constituents of these important varieties. A careful aearch of the literature revealed that 
in the entire fleld covered by chenlcal Abstracts, chenischer zentralblett and the rxperiment Station Record, only two mineral analyses of dates were reported, and these were on undescribed samples which may have been of elther Califormia or Iraa orifin. In contrast, the literature contains numirsus proxinate analyses. For the purpose of presenting a complete picture of the cherical composition of the date, a discussion of the organic composition, including vitamins, नill be first given, followed by the mineral composition. 


\section{RTVITI OF LIT :TATURF:}

1. General Chemical ioture of the Date

The orfantc compostion of the date is vell known, due to the fact that it has received attention from thee different rroups of investimators: first, those interested in human nutrition; second, those interested in comercial artificial ripenine; and third, those interested in plant physiolopy.

The date lis outstandingly a saccharine fmit, 70 to $30 \mathrm{~F}$ r cent, of 1ts ary weight consisting of surax. On the basis of a number of analyses of lresopotamian varities, the date was at first believed to contain only invert sutrer. It was later found that some Africar varietieg contained cane sugar also. Slade (38) first pointed out that tlere are tro distinct tynes of dates: tre invert sugner type, possessing at neturity a larpe amount of invert supar and $11 t+$ le or no sucrose; and the cane sugar type, possessing at m-turity practically all of ite supar in the form of sucrose. Vinson (45) shored that this difference was due to the lack of the enzyne invartase in the cone sugar type.

2. Relation of Comosition to stage of "iturity

Vinson (45) further deinsnstrated by peans of analyses at different staces of minturity tiat nen rly all of 
the sugar of a date of the invert sugar type pssseg through the cane sugar stage and becomes inverted during ripening. In a later publication, $(46)$ he presented evidence for the theory that the invertase of the unripe date is in an intracelluler forn, probably forning an insoluble compound with the protoplasm, and that during ripening the enzyme is changed into an extracellullar form readily goluble in vater. Associated with ripening also is the change of the coluble, astringent tannin into the insoluble, non-astringent forn, in which it can be seen as brown granules in the ripe date. Lloyd (31) state that this loss of astringency is due to the union of tannin with an associated collold of a carbohydrate nature. Vinson has published a bulletin (47) sumarizing his several papers on the chenistry and ripening.

Several papers have also been contributed by Fattah on the chemistry and ripening. He states (2l) that, in general, ripening involves a decrease in sucrose and tannin and an increase in reducing sugars. He and cruess (22) further report that resopotamian dates show a higher percentage of sugar and a lower moisture content than California dates of the same varipty, due presumably to more favorable climatic factors.

\section{Proxinate Analyses}

The workers whose contributions have been reviewed above were interested primartly in the physiological process of ripening, with a view to artificially accomplishing this in un- 
favorable climates, and were concerned only with sugar, molsture, and tannin contents. Another group, interested in human nutrition, has recorded more complete analyas, including the constituent usually considered to compose "proxtmete analyses," - molsture, $\mathbb{N}$-free extract, protein (H.x 6.25), fet (ether extract), crude plber, and ash, - and other constituents in some cases. Lore than a dozen such analyses are recorded in the literature. However, none of these complete analyses are described with respect to the variety of the sample. For purposes of uniformity in this paper, additional analyaes were made in our laboratory of both Hallowi and sayer varieties. These data are fiven in Table I. The samples ere packaged dates, grown in Irag in 1930 and packed by the Hills Brothers Company of Now York.

\section{Table I}

Proximate Composition of the Edible Portion of Iraq Dates.

Hallowi
(percent)

Lo1sture

19.0

15.0

Ash

2.22

1.59

protein (N $\times 6.25$ )

1.72

2.16

Fat (r.ther Extract)

1.90

0.31

Reducing sugars as invert

73.50

Total carbohydrates other than crude fiber

73.67

76.14

Crude flber

2.17

1.90

Sucrose

Wone 
The molsture content of buik dates varles from 12 to 21 per cent, from 15 to 20 per cent being that of a palatable date. It may become considerably less in storage. As the date dries out, the dextrose crystallizes, probably as dextrose monohycirate, and the date becowes knom to the trade as "sugarea". Sugared dates are considered inferior both by the trade and by the public. Fowever, they can be restored to a suitable molsture content by treatment with molst steom, as clague and sellers (15) have shown. Dates with o molsture content below twenty-tbree per cent will keep satisfactorily, because the high sugar concentration inhibits the growth of microorganisms (23).

The $\mathrm{h}$ igh percentage of sugar, approximately 75 per cent, gives the high calorific value of 1420 calories per pound (34). In this respect dates are practically on a par with $\mathrm{flgs}$ and raisius, but higher than prunes.

The percentage of protein 1 is low, approximately 2 per cent. In the date producing countries of the orient and northern Africa the natives unknowingly compensate for this by the adition of rilk to their dict of dates.

The percentage of fat is lower in the case of the analysis of the sayer variety than it is in most of the reported analyses of indescribed semples of dates. (In this connection it is also interesting to note that whereas the percentage of "fat" by ether extraction was 0.31 , duplicate 
deteralnations with petroleum ether showed only 0.11 per cent.)

Sucrose, as the table indlcates, is lacking in the Hallowi date. Both of the imported varleties, Hallow 1 and Sayer, are of the invert sugar type, while the principal American grown variety, the Deglet Noor, is of the care sugar type.

The percentage of ash is high and is comparable to that of other aried fruits.

4. Ratin of Edible portion to pit

The ratio of edible portion to pit is viriable in different varieties of dates, but at a definite molsture content is relatively constant for a given variety. Table II gives the percentage of edible portion and pit of those samples which were later used for mineral analysis. In separating the eaible portion from the pit, care was exercleed to secure as good a separation as possible, but the plts wese not cleaned. This was considered to be comprable to the separation which a consumer would make in cating unpitted dates and ejecting the stones from the mouth. (see Table II)

\section{Gums and pectin}

The avallable information on the gums and pectin in dates is very measer. Grimbert (25) wentions that gums 
Table II.

percentage of pit and calble portion*

\begin{tabular}{|c|c|c|c|c|c|c|}
\hline \multicolumn{3}{|c|}{$\begin{array}{l}\text { Description } \\
\text { of sample }\end{array}$} & Pit & $\begin{array}{l}\text { Edible } \\
\text { Fortion }\end{array}$ & $\begin{array}{l}\text { No1sture } \\
\text { in Edible } \\
\text { Portion } \\
\end{array}$ & $\begin{array}{l}\text { Ea1ble portion } \\
\text { at } \\
16 \% \text { Jolsture** }\end{array}$ \\
\hline Hallow1, & 1928 & crop & 13.4 & 86.6 & 14.8 & 86.8 \\
\hline$n$ & $"$ & $"$ & 13.4 & 86.6 & 16.0 & 86.6 \\
\hline " & 1929 & $"$ & 12.1 & 87.9 & 12.2 & 85.4 \\
\hline " & 1930 & " & 12.9 & 87.1 & 11.75 & 87.6 \\
\hline Sayer, & 1929 & " & 10.3 & 89.7 & 13.6 & 90.0 \\
\hline ", & 1930 & " & 10.3 & 89.7 & 12.3 & 90.1 \\
\hline
\end{tabular}

* Determined on amples of 100 dates each

** Calculated from the accompanying data, on the assuruption that all of the additional roisture rould be contained in the edible portion. 
and pectinous materials are present, whilo vinson (47) stateo that "pectin bodies are often present in considerable evounts and cause the fulce to jelly on lon bolling. Such jelly, prepared by the native llexicans is known as colache." No quantitative data appears in the literature.

The author oarried out a determination of alcohol precipitate, comonly referred to as "pectin", according to the method of the Aseociation of official Agricultural ohemits (2) for fruits and frutt products, on a sample of sayer dates and found them to contain 0.43 per cent "pectin" on a nolst bas18. The mo1sture content was 13.6 per cent.

The author also made a qualitative examination of the gum of sayer dates, using the qualitative tests given by Jacobs and Jaffe (27) in their method for the identification of common guns. Their method of separation of the gums prior to ident1flcation tests, however, did not take into consideration the possible presence of pectin in the material for analyses. It therefore became necessary to modify their method by introducing a procedure from an earlier paper by Cook and roodman (16) for the removal of pectin.

It was not surprising to find thet the date gum could not be positively ldentifled with any one of the comon guas included in the Jacols and Jaffe ldentificstion schewa. lowever, it appeared to resemble gum arabic in several of its reactions. 


\section{Vitanin Content}

Dates are a pood sourcs of certain of the vitamins. 4r. C. Srath and loeker (40) rave at own in a stuay of three Axizona varieties, the Derlet Nonr, the Naktum and the Thoory, that they are a rood source of vitamins $A$ and $B$ (complex), but thot they contain no appreciable $C, D$, or $G$. HCLeod and Booher (32), however, have reported that the dried date dons contain some vitamin $C$, but is a poor source of this factor. A definite antiocorbutic value was not obtnined by them because of the refusal of the andmals to eat the dates over an oxtended pexiod of time. Chan (14) reporte that fresh $\mathrm{Cl}$ inese dates contain arneclable amounts of vitanin $\mathrm{C}$. 3. L. alth (41), referring to a preliminary report of the work of $\because$. C. Smith and leeker nentioned ahove, has roted dates as "vitamin $A(t)$ " and "vitamin B $(+t)$ " on a scale giving a maximum of $(t++)$ to any food material. Neston and Leviue (44), have classed dates with the "good" sources of vitusin $B_{2}$. Shemen and gmith (37) state that dates fall in that class of ?resh verptables and frults wi ich contain frow one to ten units of vitanin a per gram. Banana, dried prume, rav and canned tomatoe, considered good sourcer, are in this roun. 


\section{EXPVRIUGTTAL PART}

\section{Analytical Methods}

\section{a. Sampling}

The objective in sampling was to obtain a representative, composite sample large enough so that all of the pronosed mineral determinations could be made upon portions withdrawn, and calculated to a common basis of moleture and ash content.

The first plan for securing such a representative sample was to accumulate a. considerable quant1ty of ash, which could be well mixed, and weighed out in suitable nortions. This proved impracticable, hovever, as no method could be devised whereby tore than about 20 grams of dates could be satisfactorily ashed in one portion. In the case of larger amounts, the heat developod within the mass from 1ts own combustion was great enough to cause slight fucion. inclusion of carbon, and probatie volatilization of alkali chlorides.

preliminary charring, grinding, and mixing of a considerable nuantity of dates was also tried as a method of aamplins, but it was found that even a small portion of this compact charred powder did not ash well.

The method finally adopted was to grind four times through a meat grinder a composite of 100 dates. The dates 
comprising this sample were selected from a larger composite consisting of bandfuls of dates from varlous parts of a 72 pound case. The desired number of clean whole dates was selected. These dates were then pitted carefuliy, so that a minimal amount of edible portion should cling to the pit. The calble portlons were then ground throuch a well-tinned meat chopper. Although the precaution was probably unnecessary with a material of this comparatively non-acid nature, the first date through the chopper was discarded for the purpose of avolding iron contamination. After the frssage of one date, the grinding surfaces remalned covered xith a sticky, protective coating.

The ground, composite sample wes then placed in a vacuum-seal quart jor, of the type used in canning, and was allowed to stand for two days, tightly covered, until presumably the moisture content had become uniform throughout the mass. Portions rere then weighed out as needed for the deteminations of moisture, ash, etc. These rithdravals were made as rapidly as possible, to avold loss of moisture. when not in use the jars were kept tightly sealed in a cool place.

\section{b. Determination of voisture}

It was necessary to deternine the molsture of the composite sauples in order that, for purposes of comparison, 
the percentages of mineral constituents in different samples could be calculated on a dry basis.

For this purpose the toluene distillation metrod of Bidwell and sterling (12) was first tried. This mothod gives a rapid and accurate detemination in the crse of substances to which It is adapted. However, in the case of biologic material containing sugar an error is introduced, because of the slow caramelization of sugar at the tenperature of boiling toluene $\left(110^{\circ} \mathrm{c}.\right)$ with the production of free water. In the case of dateg of the invert sugar type this error is particularly serious, che to the large proportion of levilose, wich cecomposes appreciably at temperatures over $70^{\circ} \mathrm{C}$. Nevertheless, the method has been applied with success to dates by $G$. H. Ireedham of the H11ls Brothers Company, who continues the diatillation empirically for a time perlod which has been found to give good correlation with noisture results obtained ky the vacuum drying nethoci.

It was thought that the same empiricol procedure could be applied to dates in the present case. However, the Bround, composite sample forned a sticky, solid mass which could not be broken up into small particles without loss both of molsture from its fresh mecerated surface and of actual particles of sanple. The naterigl was unavoldahly in large lumps, and the conditions of the distillation were consenuently anite different from those for which the 
empirical procedure had been worked out. The nethod was therefore abandoned.

The method of the Association of official Africultural Chemists (3) for fruits and fruit products mas then adopted, with some necessiry wodifications. The vacum oven avallable was not heated by an electrical unit capable of accurate control. but by a jacket of water heated by bubbling steam, an subject to variation in temperature with varlation in nrosgure in the steam line. Therefore, in order to insure agninst accidental overhesting and conseguent decomposition of the easily destructible levulose, it was deciled to run the anparatus at a level lomer than the $70^{\circ} \mathrm{C}$. recommended by the Associntion of official Acricultural Chenists, and to continue the desiccstion until the samples attained constant welcht. An attenpt was made to hold the temperature at about $50^{\circ} \mathrm{C}$., but fluctuations occurred within the range of 40 to $60^{\circ} \mathrm{c}$. The vacuun was easily maintained at a pressure well under the $100 \mathrm{~mm}$. Iimit recommended in the method.

The time recuired for desiccrtion to constant veicht was surprisingly lon . In the first get of deteminations, the Aanpleg were weldhed every day for io days before constant weight was attaincd. At the end of this poriod they were light colored and had no odor of caramelization. Subseauent sets of deteminations were desiccated without intermption 
for seven days, then weighed, replaced, and veighed again on the eighth day. No losa was found after the reven day period.

An 1llustration of the exrors which may artse then teinperatures hipher than $70^{\circ} \mathrm{C}$. are used Fas fumlohed by four sarples which were overhented by an unexpected rise in the stean pressure. These sample reached $85^{\circ} \mathrm{C}$. during one n1ght, but were otherwise treated in the nanner described above. Upon opening the oven a bumed odor could be detected, and the samples appeared darkened. The molsture content in this determination averaged 0.7 per cent higher than in a subsequent determination in wly ph poper conditions pere observea.

\section{c. Determination of Total Ash}

The deteraination of the percent-ge of ash $\mathrm{F}$. found to be dificult. The prine objective is the complete conbustion of organic matter without loss, elther mechanically or by volatilization, of any of the mineral matter. This wust be accomplished without the addition of any substance to ald combustion or to " $11 \mathrm{x}^{\prime \prime}$ the nore volatile ash contituents, the alkali chlorides.

The use of nitric acid or sulfuric acid, respectively, for these purposes changes the corposition and the weight of ths ash by replacing the natural carbonates and chlorides with the heavier nitrate and sulphate radicals. 
Careful ashing at low temperatures alone must be relied upon. Table III is 1llustrative of the variations in results onich may occur with the use of temperatures no more accurately defined or controlled than the "dull red heat" ordinarily recommended. It also, in connection with the subsequent discussion, brings out the importanoe of carrying on durlicate determinations of ash separtely rather than simultaneously If any inalcation of the correctness of the results 18 to be obtained. (see Table III)

The "parallel triplicateg" of the table were treated as follows: Approxiwately 20 grams of the corposite saixple was weighed in two or three pieces into each of three porcelain evaporating dishes. These samples were first charred in an oven over a cas stove, after which the diskes were flaced on tripodsover Bunsen burners and heated gently. The bottoms of the dishes becane faintly red, and the charred samples began to 10 at the edges. A gentle heat was maintained for one to two hours, while combustion spread throumbout the mass. When the glow had died down the dishes were placed in a mufle at a faint red heat for two hours. As the table indicates, this procedure gave three checks wich appeared to be satiafactory for materlal of this nature. A slight amount of carbon remalned, which was not driven off by a subscquent igmition at a somewhat stronger rod heat. 
Table III

Varlation in Apparent percentage of Ash in Dates with Variation in lethod of Ashing.

Conditions of Ashing
Per cent Ash in Samples (Woist Basis)

Sample Sample Sample sample Sample Sample A B I) I. F

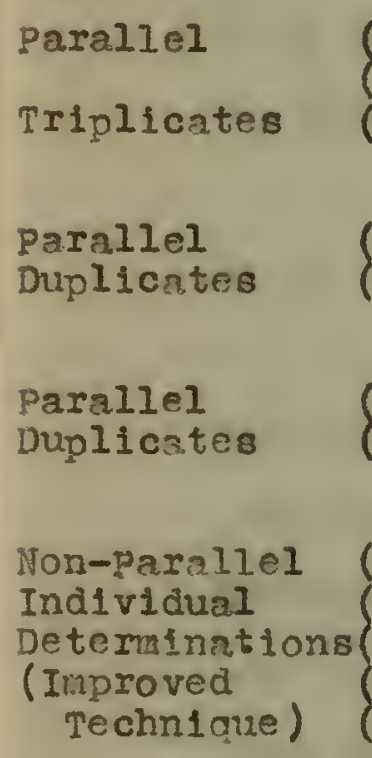

1.64

1.63

$1: 64$

$\begin{array}{lll}1.55 & 1.75 & 1.67 \\ 1.56 & 1.77 & 1.68\end{array}$

$\begin{array}{llll}1.57 & 1.77 & 1.58 & 1.64 \\ 1.54 & 1.80 & 1.56 & 1.65\end{array}$

2.12
2.10
2.11

1.68
1.65
1.67

1.67
1.67
1.66
1.68

1.71

1.71

1.72

1.72

However, subsequent "parallel duplicates", treated as the triplicates had been, while yielding satisfactory checks in themselves, showed that different pairs of duplicates on the same sample varied as vuch as .07 per cent in the percentage of ash obtained.

In order to determine whether or not this variation could be due to variations in the welght of the small carbon residues mentioned above, 12 samples were dissolved in dilute hydrochloric acid, and the solutions filtered through ignited 
Gooch cructbles. The crucibles were then drled at $110^{\circ} \mathrm{C}$. for two hours, welghed, 1mnlted at a moderate red leat, and welghed again.

It was found that if the entire loss of weight arrived at in this manner was assumed to be due to carbon, the carbon present would make the result only 0.01 to 0.02 per cent of ash too great, and rould cause a varintion between dunlicetes of not over 0.01 of a per cent. From this it appeared that the variation must be principally due to variable volatilization of ash constituents.

With this in mind, Purther deterralnations were made in the following manner:

A sample of aproximately 10 grams was welfhed out in two or three thin strips covering the bottom of a platinum evanorating dish. It mas placed in a cold nuffle furmace, and slowly chared and ashed at a temperature below any redness during a period of 8 to 12 hours. Duplicates vere not ashed simultaneously.

The results obtained by this method are given in the table as "non-parallel individual determinations." It - 111 be seen that good agreement was obtained, and that all results were higher than those previously found. The ash itself was nearly white, with much less carbon than before and with no gigns whatever of fusion. It is felt that these results are very near to the true values. 


\section{d. Deterination of $\mathrm{SiO}_{2}, \mathrm{P}_{2} \mathrm{O}_{5}, \mathrm{Fe}_{2} \mathrm{O}_{3}$,} $\mathrm{Al}_{2} \mathrm{O}_{3}, \mathrm{CaO}, \mathrm{MgO}, \mathrm{Mn}_{3} \mathrm{O}_{4}$

The method used for the determination of these elements was, in general, the gravirietric separation outIined by the Association of official Agricultural Chemists (4) for determining these constituents in plant materials. Several modifica.tions were made.

The method is subject to the criticism that it is long and cumbersome, especially in that it involves in the latter part of the process the removal of the molybdate added in the earlier part, and the destruction of large amounts of ammonium salts which have accumulated. Both of these steps are troublesome and time-consuming.

The method was adopted, nevertheless, because it was recognized as an official method among agricultural chemists. However, it has since been deleted by vote of the Association from the 1930 edition of "lethods of Analysis." The prodedure for the determination of silica is the only portion wich remains. The ner edition substitutes other methods in which each of the constituents is deternined on a separate aliquot of the ash solution, rather than by consecutive separation from one original solution.

The modifications introduced by the author will be noted in the order in which they are encountered in the procedure. The firgt wodification was thet sand was not 
separated from soluble silica, but the two were $1 \mathrm{gnited}$ and weighed together and renorted as $\mathrm{SLO}_{2}$.

The second anodfication was the introduction into the process of a deterninstion of phosphate at the point at whlch the phosplate 1 as been removed from the solution as asmonium phosohomolybdatc. preparatory to precinitating iron and aluminum $\nabla$ th ammonia. The phosplate was reprecipitated and determined as macnesium pyrophosphate, usinm the conditions of precipltation recomended by Epperson (18). These conditions were selected by the author because previous experience with Fpperson's method had invariably shown it to yleld a nagnesium amaonium phosphate precipitate of the desired choracteristics. In view of the data presented by sales (19) on the solubility of megnesium aranonium phosphate hexahydrate, sufficlent ammonia was added before the digestion period to make the solution 1.5 molar in this respect, instead of aciong the lesser amount supereted by Epperson. It is recomized by the author that the phosphorus thus determined in the ash without special sohing methods does not necessarily include all of the phosphorus in the orlfinal materinl; but it seems probable that the aiscrepancy would not be simificant in a material of this nature, wich yields an alkaline ash. The third modification was a gliglt one in the precipitation with amanium hydroxide. In vicw of the fact thet aluminum lydroxide is soluble in a slint excess of the 
reagent, the instructions to "neutralize with dilute armonium hydroxide $(1+4)$; add ahout $1 \mathrm{cc}$. excess of the reagent" were followed very carefully. It was found, however, that if after filtration two or three cublo centimeters of the reagent were added to the clear filtrate, and the solution allowed to stand for two or three hours at a temperature of $30^{\circ}-40^{\circ} \mathrm{C}$, a further slight precip 1tation of aluminum occurred. Accordingly an initial addition of four cubic centimeters, instead of one, of excess reagent was practiced with batiafactory resultw. At no time later in the process did any aluminum appent in neutral solutions to indicate that too preat an excess of ammonla had initially been added.

The fourth modiflcation was made in the washing of the amonia precipitate. IIIlebrand and Lundell (26), state that hot water cannot be used in weshing this precipitate, for aluminum hydroxide realily assumes the colloldal state. This kas found to be true. In the later stages of the washing, when the aalts had been largely removed, colloldal aluminua hydroxide berran to come through the filter. Accoraingly the suggestion of thene authors that a two per cent solution of amroniwa chlorice (two grams in 100 cubic centimeters of solution) be used for this washing wos adopted. 
The fifth modification was the use of the Jones reductor for reducing the iron preliminary to its titration with permanganate. This was regarded as having the advantages that the necessity of filtering out and washing an excess of zinc was avoided, and that any iron contamination which might be introduced in the reduction could be readily deducted after carrying out an easily performed blank determination. The conditions recommended by fales (20), were observed. (Iron was also determined colorimetrically to verify the results obtained by this method. The colorinetric method will be discussed later.)

The sixth modification was made in the process of expelling amnonium salts and removing molybdic acid, prior to the determinations of manganese and magnesium. These operations were both very troublesome. At first the ammonium salts were expelled in the manner directed, simply by evaporating the solution to dryness and then heating the dish from above until no more white fumes were given off. There was appreciable spattering in the heating process despite the exercise of extreme care. This was due to a large anount of anmonium nitrate which had been introduced into the solution with the ammonium molybdate and in the washing of the armonium phosphomolybdate precipitate. Armonium nitrate melts before decomposing and the result upon heating the salt was 
a heavy bubbling 11auid. Corplete decn position was fingliy accomplished, but some spettering had occurred. Furthereore, a stronf heat sas required to drive off the last traops of the ammonium nitrate. This heat apparently had also the effect of decomposing, most of the nolybdic acid to molybdic oxide, which is soluble in rcid. Consequently, when rydrochloric acid was added to the residue for the rurmose of discolving the desired constituents, the oxide also was dissolved, leaving only a very small residue of molybdic acid for resoval by filtration. Fortunately it was found that bolling the solution would hydrate the nolybdic oxide, to form molybdic acid again, which could then be filtered off.

It was thought that the spattexing could he avolded, and that possibly the objectionably high finlshinm temperature with its undesirable effects could be obvinted if the amonium nitrate was converted into amonium chloride. This decnnposes directly whout raelting. In order to bring this about, the solution was evonorated with hydrochloric acid as before; but the subsequent heating to expel the salts was carried only to the point at which amrorium chloride ceased to come off freely, and at wich the ammonium nitrate began to bulk:le. The fish vas then allored to cool; dilute hydrochloric acid was added; and that portion of the molybdic acid which a 
become insoluble was filtered off. Strong hydrochloric vas then added to the filtrate, and the solution was again evaporated to dryness. This was repeated several tines. Heating to expel the armonium salts was then resumed, and carried to completion, without the occurrence of spattering or the necessity of heating strongly in order to drive off the last traces.

This modification was successful as far as avolding the mechanical loss of spattering was concerned, but the molybdenum was left again in a form soluble in water, and soluble to some extent in dilute hydrochloric acid. This forr of molybdenum was of a light blue color. (Evidently in the absence of nitrates at least a part of the molybdic acid had been reduced to molybdenum blue.) By the time that the molybdenum residue remaining after the addition of dilute hydrochloric acid and subsecuent filtration had been thoroughly washed with water it had practically all dissolved and re-precipitated in the acid solution belor. This suspension was evaporated to dryness and taken up in stronger hydrochloric acid $(1+3)$. This time the residue after filtration was washed with acid of the same strength, instead of with water. A portion of the residue remained undissolved after the washing. Some advance was thus made, but a large part of the molybdenum was still in solution. The solution was once more 
evaporated to dryness.

In view of the well-known colloldal properties of molybdenum blue it was decided to take up the regidue this tive with a few cublo centimeters of strong hydrochlortc actd as directed in the method, and to try washing the insoluble restdue with one per cent salt solution. This was successful. Practically all of the molybdenum revained insoluble on the filter paper.

The seventh modification used by the author has been previously mentloned in discussing the second one. In short, the method and conditions of Epperson (18) vere again used in the prectpitation of mprestum armontum phosphate hexahydrate, this tiae in determination of magnegium at the end of the long separation.

e. Detemination of sodtum and potassium

The method used for the deterination of sodium and potassium was that of the Associntion of officinl Agricultural Chenists (5) for plants. The only modification of the fiven procedure introduced was that the precautions previously algcussed with respect to the precipitation and vashins of aluminum hydroxide were observed.

\section{f. Determination of sulphur}

The method used for the determination of sulphur in ash was that of the sssociation of Officlal Agricultural 
Cherists (6) for frutts and fruit products. It is to be noted that the amount of sulphate in the ash does not necessurly represent all of the sulchur in the original material. spocial ashing methods must be used if total sulfur is desired.

\section{Deterininetion of chlorine}

Chlorine was deterninea by the method of the Assocition of Official Africultural Chemists (7) for fmits and frut products.

h. Detemination of Iron (Coloximetric)

Particular interest attaches to the percentare of Iron because of the simificance of this element in nutrition. For this reason 1t was desired to verify the results obtained by the gravinetric method of the Assoctation of Official Africultural cherists, by means of a direct deterination which would eliminate the possibility of contarination from reagents. For the detemination of very smil amounts of iron, colorimetric netrods are most suitable. Stufart $(43)$ in a recent paper lias fiven an excellent discussion of the existing metrods for the determination of iron in biological materials. Mis modification of the thiocyanate method was used by the author. ixtreme care ras taken to avold contanination with 1ron in any way. 
A comparison of the results obtained by this nothod with those previonsly obtained by the sravinetric metrod is of interest. The percentame of iron in ash obtained colorimetxicnlly was lower than that obtalned in the rravimotric geparation. This was to be excoted, since three of the reaprnts used in the fomer doternimation oontained traces of iron. The hydrochloric acid contained, according to the label analysis, not over 0.00005 per cent; the nitric acid, not over 0.0002 per cent; the nyrosulmate, not over 0.00006 per cent. Trese reagents were used in somewint indetominate amounts. However, a rouph calculation, based on the assinntion that they contened the raximum amounts of iron allored by the labels, indicoted thot in four saples an average amount of $\mathrm{Fe}_{2} \mathrm{O}_{3}$ eouivalent to 0.063 par cent of the ash had been added. The averome of results obtained by the colorimetric notrod was 0.06 per cent lower than the averace of trose obtained by the ori inal pravimetric motlod. This correlation sefis a cood verifichtion of the correctness of tle data, olthoum it is baged on the label snalyses, whlch were not rortfind.

\section{Dntemination of Copper}

The recently oiscovered physiolopical innortance of copper has slso turned especial interest toward the 
developrent of methods for deternining accurately the occurrence of very s:nall anounts of tlis element in biological naterial. The most recent contribution to this subject 18 that of Ansbacher, Remington and Culp (1). Their nethod was used by the author. Extrene care was used to prevent any contamination with copper, and all reamente were tested for its presence. The distilled water was redistilled in glass apparatus before use. Sone modifications in technique were introduced, wh ich were thought to lessen the danger of contamination. The ret-ashing alternative was used in preparing the samples.

j. Deterrination of Boric acid

Boric acid was determined by the Gooch mpthod, as described by Logch (28).

k. Deterination of Mlkulinity

The uncthod used for the determination of alkalinity vas that of the Association of official Arricultural Chenists (8) for fruits and fruit producta.

2. General Composition of the Ash

The percentage conposition of the ash of Irad dater of tle llallowl and sayer varieties, as detemined by the author, is shown in Table IV. Fachcolumn of anta is 
the analysis of a sarple representing a 72-pound case of rulk dates of the verioty and crop desigmated. The determination of each element except copper was made in dunlicate, and the determintions of percentage of ash and of $\mathrm{SO}_{3}$ were made in triplicate. (see gable IV)

The first point to be noted in the table is the nercentare of ash in the dry date, approxiaately 2 per cent. This is two or three times as hish as that of most of our foods which yield an alkaline ash. Lost fresh fruits and many vegetalues have less than 1 pri cent of ash. other arird Imits, such as prunes, and ralsins, have a percentspe of ash which 1 comparable to that of the date. Ilowever, In consideration of the mamner of their use in the dictary, dates c33 nore fairly be compared oith fresh fmits than with dried anes.

The second point to be noted is the lares proportion of potash in the ash. This is an important factor in the 1 im alkalinity, which will be discussed later.

other constituents of particular interest are iron, manganese, and copper. These also w11l be discussed later in connection with the work of other analysts.

lable $V$ presents for coaparison tre only mineral analyses of dates reported in the literature, and the averafes of the author's analyses of the Kallowi and sayer varinties.

The analyses are in good arrecunt, except in a few particulars. The percentage of Ma $\mathrm{N}_{2} \mathrm{O}$ otained by forbea, 
Table IV.

Perentere colpostion of the

Asl of Iraq Dates

\begin{tabular}{|c|c|c|c|c|c|c|}
\hline Variety & \multicolumn{4}{|c|}{ KaIlow1 } & \multicolumn{2}{|c|}{ Sayer } \\
\hline Cron & $1928 \mathrm{~A}$ & 192813 & 1229 & 1930 & 1929 & 1930 \\
\hline $\begin{array}{l}\text { Ash content, } \\
\text { dry dotes, } \\
\text { r I cent }\end{array}$ & 2.40 & 2.51 & 1.90 & 2.14 & 1.93 & 1.95 \\
\hline$K_{2} O$ & 46.9 & 46.0 & 42.2 & 43.2 & 41.2 & 40.5 \\
\hline $\mathrm{Na}_{2} \mathrm{O}$ & 2.02 & 2.65 & 2.80 & 2.15 & 2.55 & 2.76 \\
\hline CaO & 4.35 & 3.88 & 4.75 & 4.27 & 6.34 & 7.58 \\
\hline 180 & 5.31 & 5.45 & 6.34 & 5.38 & 6.64 & 6.30 \\
\hline $\mathrm{SIO}_{2}$ & 5.81 & 7.40 & 7.01 & 7.03 & 7.80 & 6.69 \\
\hline $\mathrm{Fe}_{2} \mathrm{O}_{3}$ & 0.21 & 0.23 & 0.32 & 0.20 & 0.27 & 0.19 \\
\hline${ }_{3} \mathrm{O}_{4}$ & 0.20 & 0.15 & 0.25 & 0.21 & 0.26 & 0.110 \\
\hline $\mathrm{CI}$ & 16.90 & 19.16 & 12.01 & 14.65 & 15.46 & 17.83 \\
\hline $\mathrm{SO}_{3}$ & 6.19 & 6.33 & 6.99 & 5.91 & 7.26 & 7.90 \\
\hline $\mathrm{P}_{2} \mathrm{O}_{5}$ & 7.89 & 7.38 & 10.12 & ह. हु马 & 8.13 & 6.81 \\
\hline Cuo & & & 0.017 & 0.012 & 0.013 & 0.015 \\
\hline $\mathrm{AI}_{2} \mathrm{O}_{3}$ & 0.50 & 0.46 & & & & \\
\hline
\end{tabular}




\section{Table v.}

\section{Percenta Comnosition of tis Ash of Dates \\ (Complled from different gources)}

\begin{tabular}{|c|c|c|c|c|}
\hline Bourer of Taid & nonoy (9) & $\begin{array}{l}\text { forbes, Bremle } \\
\text { 'crsching (24) }\end{array}$ & \multicolumn{2}{|c|}{ T) is Investifsotion } \\
\hline Vaxloty & (not stoted) & (not stated) & IIRI IOE 1 & 3ayex \\
\hline No. of yamples & 1 & 1 & it & 2 \\
\hline $\begin{array}{l}\text { Ash content, } \\
\text { dry dates, } \\
\text { mrs cent. }\end{array}$ & 2.04 & 1.92 & 2.24 & 1.94 \\
\hline$K_{2} O$ & 15.04 & 41.8 & 44.6 & 10.8 \\
\hline $\operatorname{lig}_{2} \mathrm{O}$ & 2.36 & 8.09 & 2.111 & 2.55 \\
\hline $\mathrm{C}=\mathrm{O}$ & 6.63 & 6.12 & 4.31 & 6.96 \\
\hline Mro & 6.52 & 7.42 & 5.62 & 6.77 \\
\hline $310_{2}$ & 5.77 & & 6.81 & 7.24 \\
\hline $\mathrm{PE}_{2} \mathrm{O}_{3}$ & 0.47 & & 0.24 & 0.23 \\
\hline $\mathrm{Ln}_{3} \mathrm{O}_{4}$ & & & 0.20 & 0.33 \\
\hline $\mathrm{CI}$ & 19.06 & 14.85 & 15.43 & 16.64 \\
\hline $\mathrm{SO}_{3}$ & 7.35 & 11.32 & 6.36 & 7.62 \\
\hline $\mathrm{P}_{2} \mathrm{O}_{5}$ & 0.78 & 9.18 & 8.57 & 7.47 \\
\hline CuO & & & $0.015 *$ & 0.014 \\
\hline $\mathrm{Al}_{2} \mathrm{O}_{3}$ & - & & $0.48 *$ & \\
\hline
\end{tabular}

- tuo sanplas oujy 
Bremle, and yensching (24) is distinotly ligher than that obtained by eithor Benoy (9) or in this investifation. Th19 may be aun to the fact that rorbes and his cororkers used an nrleinal wethod for detemining the totel of sodius and cotassium, while bot? Benoy anì the autior used the method of the Association of official Arxicultural Chemists (5). In each case sodium itself was detemined by difference, frow the result for total sodium plus potassium, the latter bein determined directly by the chloroplatinate method.

The result for percentare of $\mathrm{SO}_{3}$ ootained by Forbes nnilif coworkers is also hisher thon that obtained by elther penoy or in this investigation, altheuph perhaps not beyond the rampe of biological varlation. It represents total sulfur in the naterial, however, while the results of of this rescarch are on sulfur in ash. It seens unlikely thot this fact rovid account for the difierence, in the case of a matrial of alkaline ash and of such a low protein and fat content. Whotiex Benoy's value raprescnts total sulfur or sulfur in ash is not stated.

Anothex distinct difference is fourd between the nercentares of phos horus reported by Denoy, end those reportrd by both Forbes anc ris coworkers and this investigation. This geems to be wore than a. normal variation. No explanation other than a posible error in deolmal noint can be sugirestod. 
3. Content of Iron, Copper and Manganebe.

Table VI presents all of the data on the tron content of dates wioh is to be found in tis literature, together with the data obtained in tis investipation. (Sะe $T$ ?

The iron is reported on a molst lasis, since some of the data in the original articles were presented on a moist, or "as purchased", basis without infornation as to the moisture content. Where infomation on this point was liven it is included in the table.

The data show the variation characteriatic of blologic naterial, but all are in the gave general rane. Stiebeling ('t?) has complled a table of the iron contents of fresh frults and vegetables, and from tlis compliation has made an arbitrary claselfichtion of 98 of then a.s poor, fair, cood, and excellent. Those containing over 0.0016 per sent of iron, she considers "excellent." Spinach, chnrd, dandelion reens, an Ilma beans are exmplos of this class. It is evident that dates are in the class with these vaterials. Howpunx, it must be renembered that dates are much loper in moisture content anc mould apponr less favorally if comparisons trex wade on a dxy basis.

Table VII presents the only reports on tie coppeI and manganese content of dater wh loh are to be found in the literature, tomether wth the dita obtained in th is investipation. (see $T=1$ is $V I I$ ) 
Table VI.

Iron contert of the zable portion of Dotes (Volst basis)

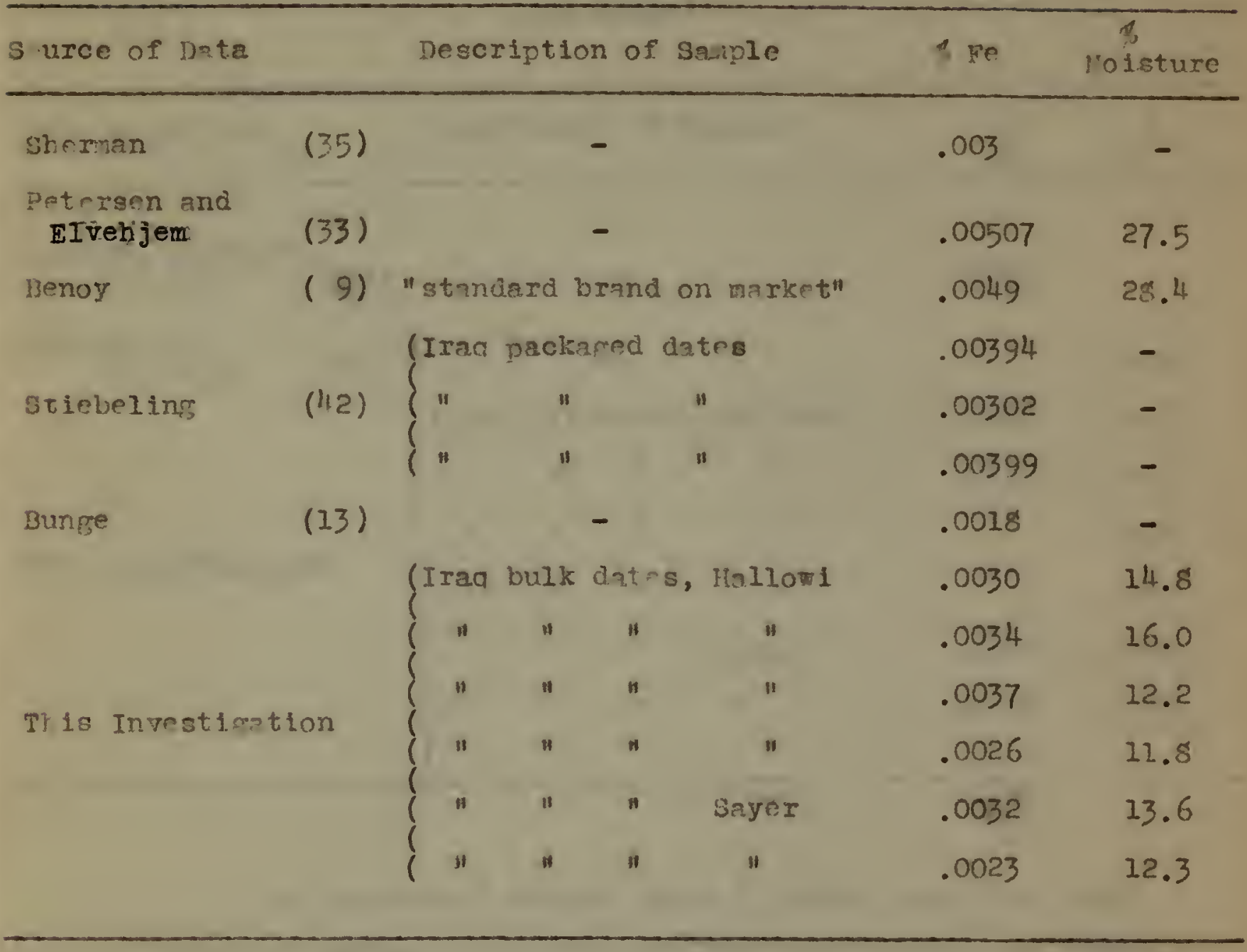


Table VII

Copper and Manganese content of the Fible

portion of Dates

(Dry basis)

Source of lorta Description of Salple

$(30)$

$-$

petergen

Lindor ani

jetersen

(29)

This Investigation
(29)

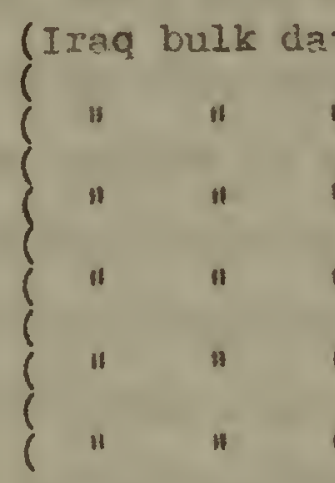

Cu

$\ln$

The anount of copper found is lorer than that found by I,inciow, Livehjem, and petersen (30), but in the sace general rance. These authors have detemined the copper content of 160 diferent food meterials, and rave clissified trem, in descendin order of coprex content, on a fresh basis, as folloms: nuts, dried legumes, cerenls, dried frults, poultry, 
fish, antual tiscues, ereen legumes, roots, etc., lenfy verentables, fresh fruts, and non-leafy vegetables. The deta obtained by the anthor would on this wolst basis of comparison drop dates below the averare of drled frults dom to the class average of fish.

There is a distinct difference between the percentame of manfanese obtained by Lindow and petersen (29) and that obtained in the present investigation. Th is aifference is difficult to explain. Thile it is truo that Lindow and Petersen analysed only one cample of dotes, in contrast to the author's six samples, they have the amporting evidence that other dried fruits wis ich they analyged fell in the same raner. The uniforaly higher results of the anthor on six samples from the same locality could be due to the anture of the soll. The analytical mothod used by Lindow and Elvehjem was undoubtedy better than that used by the author. It was dicet, wereas the author's method spparated manganese in the course or n lone gravimetric deteraination thich included first the determinstion of several other constituents. No manpanege was shown in the label analyses of the rengents used, but its mitire abgence prs not verified. However, as kas been at omn, the amount of iron added in the reasents was slight, ard it seens very urikely that manganese contamingtion, thich was not even mentioned on the labels, could be three or four times greater than the iron contamination. 
The author believes that the large omount of manganese reported is not due to any contamination with other elements in tien precipitato weighed. A study of the metrod, in connection with incidental observations in the course of the doterninntion, makes it acen certnin that the precinftete could not hove been contaminated with silica, iron, or aluminum.

\section{Content of Boric scid an zinc}

The availoble data on the torlc acid content of dates is shin in Toule VIII.

\section{Table VIII}

Boric heid content of the Edible portion of Dates (roist basis)

\section{Source of Data}

Description of Sarple \& $\mathrm{H}_{3} \mathrm{BO}_{3}$

Smith, A. IT. (39) $-$ .03 Dodd (17) Jersian dates .006 T1 is Investigation Irag dates, sayer variety, 1930 .037

Silth (39) male determinationg nil six dried frults and found they to contain from 0.002 por cent to 0.008 per cent of boric acid with the exception of the date, which contained 0.03 per cent. The author's value arroes well with 
that obtuined ky Selth. Dodd (17) has analysed about 50 fruits and veretnbles, and las found them to contain from 0.0 per cent to 0.025 per cent. Each malyst ras eraployed a different nethod.

Zine has been deterined in a large number of frults and vegotables by Bertrand and Benson (10). bates were found to contain $3.4 \mathrm{mg}$. per kilo of fresh anterial; $4.3 \mathrm{mg}$. por kilo on a dry basis; and 94 age per kilo of ath (II). Compared on the basis of fresh ratarial trey tave a higher cinc contint thrs any of the fruits listed. Ihese Include oranges, lemons, peacles, pluas, apricots, stramberries, bananas, and tomatoes. They fall in the class with tumips and asparapus.

\section{AIkalinity of the Ash}

The alkalintty of the ash is piven in Takle IX. The date presented from Benoy (9), and from Forbes, Bepple and lenschime, (24) was calculated by the autlor fron the minaral. analyses given by thesa. Hone of the data from any of the analyats aiffers significantly from the general trend. The titration data of the author presents the averaces of triplicate deteminations.

The alkalinity, as calculated on a dry basis, is not Fich in comparison with otler fruits am vepotables. Fowever, when a comparisor is zinde on the "as purchased" basis the 
Table IX.

potential Alkallnity of jateg *

Source of Data

Descrintion of 3anple

Alkalinity Alk?linity calculatiod dotorilued Prom by

analys 1 *** 4tration

Sherinn** *

(36)

$-$

13.8

Benoy

(9) "st-ndnsd brand on market"

17.6

Forbes, permie,

lienchines

$-$

17.5

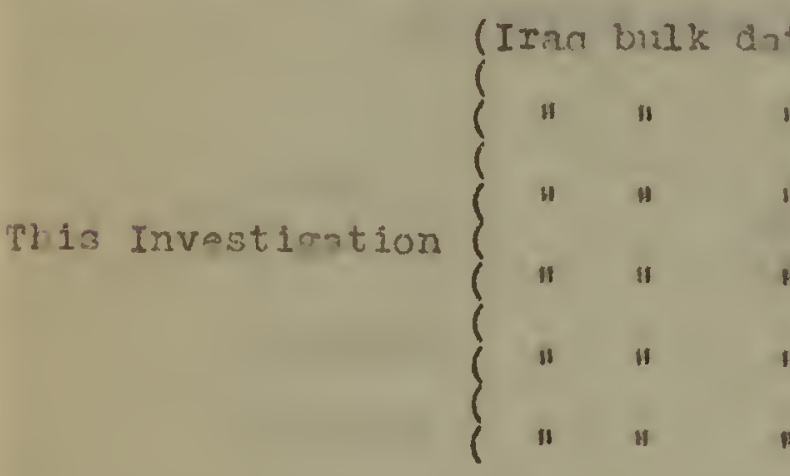

$\begin{array}{cccc}\text { Ir3110w1, } 1928 & 17.7 & 17.0 \\ \text { " } & 1928 & 17.5 & 16.9 \\ \text { " } & 1929 & 15.7 & 16.65 \\ \text { Sayer } & 1929 & 15.5 & 16.7 \\ \text { " } & 1930 & 15.2 & 16.3\end{array}$

* Exese of ban-forming over ac1k-forming constituents in tie asl from 100 cruts dry matprial, fxpressed as cublc centimeters of nomal olkñil.

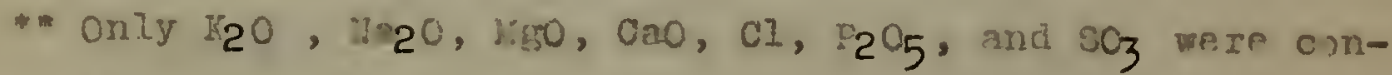
sidereas.

** Tre value fiven in the reference 13 on 2 moist basis. The vilue lage piven is calcul ted on the sesumpton of $20 \%$ moieture content. 
date hecoses one of the best of the "rotential alkalinity" sources. Data from Sheman $(36)$ is presented in Table $x$ to illugtrate this point. (see pable $x$ )

The value given for dates in thig tahle is the average of the author's results on six samples. The whole table is baged on tie alkolinity calculated from mineral analyses rether than on values obtained by tbe titration nethod.

\section{Table $x$}

Poteatial Alkalinity of Foods

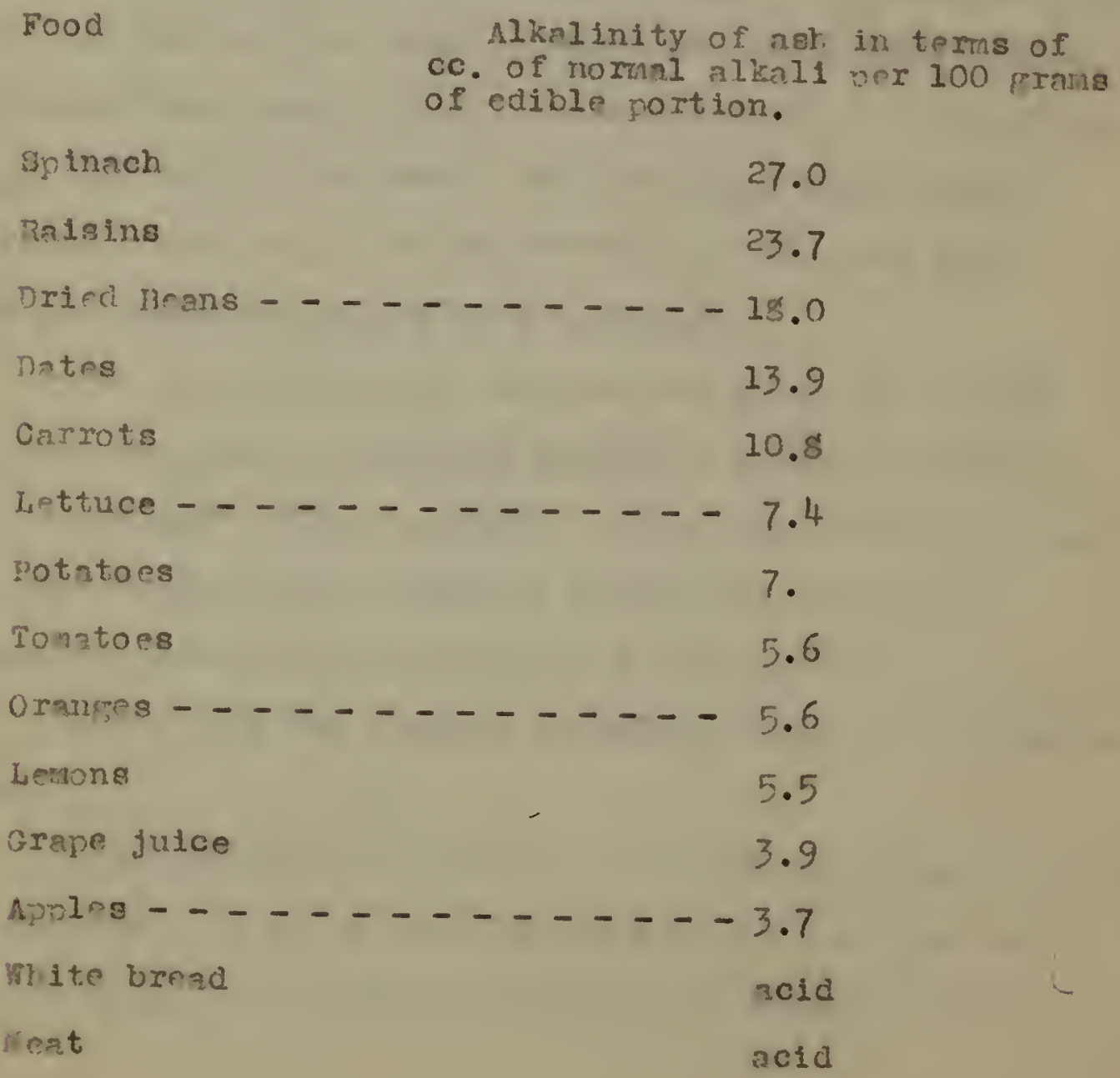




\section{IV. sบบ}

Cowplete mineral anzlyses of gix samples of dateg, covering two vorinties and tl ree crop seasons, were wade. yo maxked differences wree observed in the awount or composition of ash in the orops from different seasons. Th.18 vas true of both Hallowi axl Gayer virietins. Slmilarly thern were no striking differences between three tro varieties. The porcentage of asl is hich. On a molsture-free basis it varied from 1.9 to 2.5 per cent. The outstanding claracteristic of the ash Fas the kigh proportion of potath, wich comrised from 40 to 47 per cents of the total. other principal bace-forming constituents vere: Coo, 4 to 8 per cent; 10,5 to 7 pnr cent; and $\mathrm{Na}_{2} \mathrm{O}, 2.0$ to 2.8 per cent. The princival acid-forning constituents were: $\mathrm{Cl}, 12$ to 18 per cent of the ash; ${ }_{2}{ }_{2}{ }_{5}$, 7 to $1 \theta$ per cent; and $3_{3}$, 6 to 8 por cent.

The iron contert of tis date was found to te high for alant matrial, comprising 0.0025 to 0.0037 per cent of the "as nurchased" edible portion. On the sarme basis the comar content was fairly high, 0.0002 to 0.0003 per cent, ane inongmese foun? to the extent of 0.003 per cent. Toric acid was present as 0.04 per cent of the rdible portion.

High alkslinity was mother outstandine charocteristic of the date ash. The ash from 100 pros of dry matrrial pas equivalent to 15 to 17 cubic centimeters of noralal alknli. 
pectin (alcohol precipitate) ras present to the extent of 0.43 per cent in a sample of snyer dates. oualitative exarination of the mu from sayer antes showed that it resembled gur arabic in some of its reactions. The exact nature of the gum was not determined.

The nroportion of edible portion to pit is a variety characteristic. The Hallowi pits constituted 13 per cent of the total welght of the date, compared $\pi 1$ th 10 per cest for the s?yer.

The large proportion and aeli-balanced distribution of the minerals, and the $h$ igh surar content, make the date a valuable adjunct to the dift. 


\section{BIBLIOGRADHY}

1. Ansbacher, S., Remlngton, R. I., and oulp, r. B. "Copper Determination in Organic vatter." Ind. Eng. Chem., Anal. Ed., 3 , 314-17 (1931).

2. Association of Official Agricultural Chemists "liethods of Analysis." Association of Officlal Agricultural Chemists, Washington, D. C. second ed. Chap. XIV, Sec. 13, 212. (1935).

3. IbId., chapter XIV, Sec. 3, 209.

4. Ibid., Chapter IV, Sec. 2, 3, 5; 39-4I.

5. Ibid., Chapter IV, sec. 9, 42-43.

6. IbId., Chapter XIV, Sec. 10, 211.

7. Ibld., Chapter XIV, Sec. 12, 211

8. Ibld., Chapter XIV, Sec. 9, 211.

9. Benoy, H. P., "The uneral content of the Jujube." J. Agr. Res. 39, 949-51 (1929).

10. Bertrand, G., and Benson, B., The Zinc Content of Food Vegetables", Compt. rend. 187, 1098-1101 (1928); C. A. 23,1696 .

11. Bertrand, G., and Benson, $B_{\text {. }}$, "The Zinc Content of the Chlef Vegetable Foods." Bull. soc. hyg. aliment. 16, 457-63 (1928) C. A. $\underline{23}, 2505$.

12. BIdwell, G. I., and Sterling, w. F., "preliminary Notes on the Direct Determination of Molsture." Ind. Eng. Ohem. 17, 147-9, (1925).

13. Bungè, G., "Der Kalk - und Eisengehalt unserer Nahrung." Zt schr. B101. 45, 532-39 (1904).

14. Chen, C. Y. "Vitamin $C$ in Chinese rood Naterials" Sclence (China) 15, 931-6 (1931);C. A. 25, 5446.

15. Clague, J. A., and Vellers, C. R. "Time - Temperature Humidty Relations in Dried Fruit Pasteurization. J. Eact., 211, 30-31 (1931). 
16. Cook, A. A., and Woodman, A. G. "The Detection of Vegetable Gums in Food Products" Ind. Eng. Chem. 10, $530-33$ (1918).

17. Dodd, A. S. "The Natural Occurrence of Boron Compounds in Fruits and Vegetable Products" Analyst, 54, 15-20 (1929).

18. Epperson, A. V., "The Pyrophosphate Method for the Determination of Magnesium and Phosphoric Anhydride." J. Am. Chem. Soc., 50, 321-7 (1928).

19. Fales, H. A., "Inorganic Quantitative Analysis" The Century Co., Ner York, par. 191 (1925).

20. Ibid., par. 273.

21. Fattah, M. T., "Chemical Studies of Dates." Date Grower's Imst.Rpt., 4, 10-12 (1927).

22. Fattah, M. T., and Cruess, W. V. "Factors Affecting the Composition of Dates." Plant Physiol. $\underline{2}, 349-$ 55 (1927); C. A. $\underline{22}, 4153$.

23. Fellers, C. R., and Clague, J. A., "Souring of Dates by Yeasts." J. Bact. $\underline{22}, 63$ (1932).

24. Forbes, E. B., Beegle, F. M. , and Mensching, J. E. "Mineral and Organic Analyses of Foods." Onio Expt. Sta. Bul1. 255.(1913).

25. Grimbert, J. (Title not known) J. de Pharm. 20, 485 (1889) (Reference found in) Wehner, C. "Die Pflanzenstroffel Gustar Fisher, Jena. (I9II).

26. Hillebrand, W. F., and Lundell, G. E. F., "Applied Inorganic Analysis" John Wiley and Sons, Inc., New York, 394 (1929).

27. Jacobs, M. B., and Jaffe, L. "Method for Identification of the Common Gums." Ind. Eng. Chem., Anal. $\$ d$. 210-12 (1931).

28. Leach, A. E., "Food Inspection and Analysis", John Wiley and Sons, Inc. 4th ed., 887 (1920). 
29. Lindow, C. Content of plant and Animal Laterials." J. B1ol. Chem., 75, 169-75 (1927).

30. Lindow, C. W. Elvehjem, O. A., and Petersen, "The Copper Content of Plant and Animal Foods." J. Blol. Chem. 82, 465-71 (1929).

31. Lloyd, F. E., "Development and Nutrition of the Fubryo, seed, and Carpel in the Date." Mo. Bot. Gard. Ann. Rept., 21, 103-164 (1910); Expt. Sta. Record 24, 629.

32. WcLeod, G. and Booher, L., "The Antiscorbutic vitamin Content of Some preserved Foods." J. Home Econ. 22 , 588-93 (1930).

33. Petersen, ".. H., and $\mathrm{I}$ veh $\mathrm{em}, \mathrm{C}$. A., "The Iron Content of plant and Animal Materials." J. Blol. Chem. 78; 215-23 (1928).

34. Sherman, H. C. "Food Products" The Mecullian Co., New York . 337 (1914).

35. Ibid., 348

36. Ibid., 353.

37. Sherman, H. C., and Smith, S. L., "The V1tamins." Chemical Catalog Co., Inc., New York, 269 (1931).

38. Slade, H. B., "Invert and Cane Sugar Dates." Rept. Ar12. Agr. Expt. Sta. 17, 164, (1906).

39. Sinith, A. H., "Boric Acid Occurrine Naturally in Some Eruits." Ohio. J. Sci. 17, 66-8 (1916).

40. Smith, M. C. and Heeker, L. A., "The Vitamin Content of Three Varieties of Dates." Univ. of Arlz. Agr. Expt. Sta. Tech. Eull.34. (1931).

41. Smith, 3. L. "Vitamins in Food Materials." U. S. D. A. Circ. 84 (1929).

42. Stlebeling, H. K., "The Iron content of Vegetables and Fruits." U.'S. D. A. C1rc. 205 (1932). 
45

43. Stugart, $M_{.}$, "Determination of Iron in Milk and other Biological Materials." Ind. Eng. Chem., Anal. Ed., 3, 390-93 (1931).

44. Weston, W., and Levine, H. "Vitamin Chart" Ind. Eng. Chem., News Ed. 10, 31 (1932).

45. VInson, A. E., "The Function of Invertase in the Formation of Cane and Invert Sugar Dates." Botan. Gaz., $43,392-407$ (1907); C. A. 1, 2420 .

46. Vinson, A. E. KEndo- and Ekto-Invertase of the Date." J. Am. Chem. Soc. 30, 1005-20 (1908).

47. Vinson, A. $\mathbb{E}$. , "Chemistry and Ripening of the Date." Univ. Ariz. Agr. Expt. Sta. Bull. 66,403-35 (1911). 
VI. ACKIOWLEDGWEITS.

Acknowledgenents are extended to Dr. C. R. pellers and prof. W. Norse, an: to the other meabrs of the college faculty who lave so generously given their counsel. Ackoviederment is also made to the Hills Hrotlexs Company of Irng York whici hag suppoxted the pellowship under ich th is inveatigntion has been made. Phanks are further due to tle executives and chemists of the company, who have extended the facilities of the company in providing samples and peneral infornation. 
Approved by:

CareRtevers

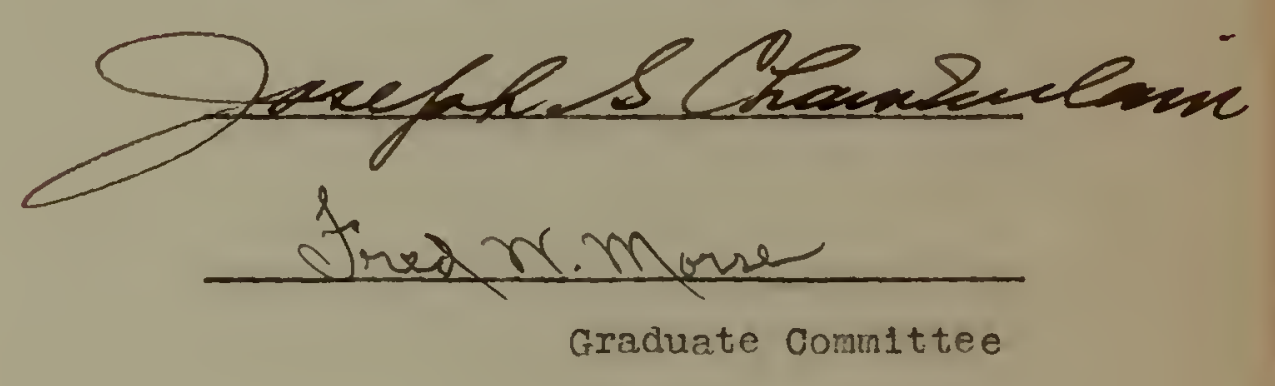

nate May 31, 1932 

